\title{
Recent Institutional Reforms in the Foreign Trade System of the People's Republic of China: Some Current Issues
}

\author{
HATLA THELLE
}

An important part of China's comprehensive reform programme in the last ten years has been the reform of the economic, institutional and legal framework of foreign economic relations and trade. »The Open Door Policy « is the second part of the overall slogan of the current period of Chinese history, calling for "Economic Reform and Opening to the Outside World, « and is an integral part of China's new development strategy.

\section{Reform}

One of the most radical and outstanding parts of this reform have been the cutting up of the nation into different regions with different economic possibilities and conditions. Since the establishment of the first Special Economic Zone (SEZ) in 1980 until the formulation of the "Costal Region Strategy « in 1987 the granting of special privileges concerning economic relations to the outside world have gradually expanded to include a very great part of China's industrialized regions, involving an area of 325.000 $\mathrm{km}^{2}$ and a population of 200 mio. people. Another outstanding feature of this reform is the fact that foreigners with the promulgation of the "Law on Chinese- Foreign Joint Ventures « in July 1979 for the first time since 1949 have been allowed to invest money in the Chinese development. These two phenomena have won world-wide attention and caused analysis and debate among Western scholars. Not less important, however, is the systematic reform of the more regular trade activities and the introduction of a whole range of new possibilities for economic cooperation between Chinese enterprises and foreign partners.

This article focuses primarily on the problems connected with this last part of the reform, i.e. the regional and sectoral decentralization of decision-making at the nation-wide level, because the situation in the 
southern and coastal parts of China is judged to be well described and analyzed in existing literature.

\section{Decentralization}

The reform of the trade activities follows the general reform policy of the Chinese government in recent years, perhaps in a more cautious way, with the main focus on transfer of decision-making power to lower levels with the aim to make production enterprises economically self-regulating, and on the handling of the interplay between the individual, the organizations and the state through the signing of contracts. The state gets its share from taxation rather than from transfer of profit followed by central allocation of resources.

Decentralization of economic decision-making in foreign trade procedures has been a gradual process since 1979. Prior to 1978 all foreign trade was conducted through about 10 centralized Foreign Trade Corporations (FTCs) under the aegis of the Ministry of Foreign Trade. Even now most trade is carried out through specialized FTCs, but by a much larger number of them. Following the introduction of reform, ministries and provinces were allowed to set up FTCs outside the realm of central control. The exact number of these corporations is unknown, but figures up to 5000 have been mentioned. Only Sino-Foreign Joint Ventures (JVs) and a few big Chinese enterprises have been granted direct trading rights.

In 1979 new institutions were created to regulate the new activities and the whole top level was reorganized in 1982, when the Ministry of Foreign Economic Relations and Trade(MOFERT) was established by the merging of the Ministry of Foreign Trade with the Import Export Commission, the Commission of Economic Relations and the Foreign Investment Commission, bringing the jurisdiction of foreign trade and foreign investment under the same ministry. In 1984 this Ministry issued a decision identifying the most important parts of reform of the foreign trade system as follows: 1) To separate government and enterprise management (zheng qi fenkai), which implies that the corporations and enterprises should be responsible for their own profits and losses (zifu yingkui). The Ministry is to regulate foreign trade only by administrative and economic measures. 2) To unify production and trade by allowing some enterprises to trade directly with foreign countries (gongmao gongsi, nongmao gongsi, jimao gongsi are the names for enterprises integrating industry with trade, agriculture with 
trade and technology with trade).3) To introduce an agent system (dailizhi) for import and export. ${ }^{1}$

The method to make the foreign trade enterprises responsible for own profits and losses is to introduce the contract responsibility system (chengbao zeren zhidu). This system was tried out in 1987 in three selected industries: light industry, arts and crafts industry, and the garment industry, where the enterprises sign contracts with the FTCs who again sign contracts with central authorities. In the beginning of 1988 the State Council decided to extend the use of this system to the whole foreign trade sector. Responsibilities, rights and privileges are allocated between the state and local authorities, between local authorities and foreign trade enterprises and between foreign trade enterprises and enterprise workers via three separate norms: a target for income from export, a target for income of foreign exchange to be delivered to the state, and a target for total profit. Attainment of the target is linked to reward at every level. Above-target profit of foreign exchange is divided between the state and the lower level at a ratio of $2: 8$, i.e $20 \%$ to the state and $80 \%$ to the locality or enterprise. This ratio is mentioned as some kind of standard ${ }^{2}$, it can ostensibly vary from one region or sector to another. At the corporation level I have heard figures of $55 \%, 70 \%$, and $20 \%$ retained, but the criteria for determining the figure is not clear. It is stated to be «according to circumstances."

The granting of the right to trade directly with foreign countries have until now been reserved for very big enterprises, mostly at the provincial level.

The introduction of the agent system - the last of the three aims mentioned in 1984 - is still only proceeding very slowly. For instance in August 1989 in the city of Harbin five of the biggest FTCs had either not instituted it at all or only on a very limited scale.

Along with the decentralization scheme a host of opportunities has been opened for new forms of trading in the form of compensation trade (buchang maoyi), processing agreements (lailiao jiagong) and assembling contracts (laijian zhuangbei). These forms blur the distinction between trade and investment, their main characteristic - roughly speaking - being that a foreign partner supplies the Chinese with equipment and/or material and is paid with products from this equipment or from another production. These forms are regulated by contracts approved by local authorities, and are covered by general laws concerning taxation, import duties, licensing etc. 


\section{Foreign Investment}

Direct foreign investment takes the form of equity joint ventures (shewai hezi jingying qiye), contractual joint ventures (hezuo jingying qiye) and cooperative development of natural resources (hezuo kaifa), particularly off-shore oil. An equity joint venture is to be a limited liability company with at least $25 \%$ foreign capital, and the chairman of the board is to be a citizen of China. A cooperative venture is a much looser form. It does not have to constitute a legal person, but can be any contracted agreement on a certain kind of production. A last category is wholly foreign owned ventures where a foreign company is allowed by law to establish an enterprise on Chinese territory without any Chinese capital involved. This is almost exclusively permitted in the SEZs. Development of natural resources is covered by a special law-complex, which shall not be further elaborated here.

Experiments with absorption of foreign capital are most radically tried out in the coastal area. At the moment there exist five regular SEZs (jingji tequ), situated in the southern part of the coastal region: Shenzhen, Zhuhai, Shantou, Xiamen and Hainan Island. The first four were established in 1980, Hainan was made a province as well as a SEZ in April 1988. The zones are physically demarcated areas in traditional farming land. Guangdong and Fujian provinces, where they are situated, are empowered to formulate development plans, to approve investment projects, handle land allotment, provide staff and workers, and establish cultural and health facilities. On the other hand, they are also obliged to provide public utilities as water supply, drainage, power, roads, wharves, communications and warehouses. Thus the SEZs are essentially provincial undertakings, although governed by general regulations approved by the National People's Congress. According to these regulations raw material, equipment and so on imported by investors into the zones are exempted from duties, and products for export are exempted from taxes, while products for domestic sale shall be taxed. The income tax rate of enterprises is half the tax on the mainland, that is $15 \%$ of taxable income, and profits remitted abroad are not taxed. The zones have, moreover, been allowed to transfer land-use rights for »compensation, «i.e. to sell the right to use a certain piece of land for a fixed period of time (mostly 50 years) to foreign investors. The price is negotiable below a fixed limit. This right has until now been reserved for the SEZs and the largest cities, but recently a state official 
disclosed that some big and medium cities, including several inland ones, are expected to obtain this right later in $1989 .^{3}$

In November 1984 the possibilities of preferential treatment of foreign investors were broadened to include the socalled economic and technological development zones (jingji jishu kaifa qu) in 14 port cities along the east coast. In April that year the State Council made a decision to open these cities (under the name of yanhai kaifang chengshi) which, in contrast to the previously established zones, are industrially and commercially developed. As a concrete manifestation of the decision the authorities were to establish demarcated zones within their areas, where tax and duty concessions similar, or almost similar, to the SEZs, were given. Again it is the provincial (or the city in case of a plan-independent city) authorities who are to invest in infrastructure, energy supply, drainage, etc. possibly in cooperation with foreign investors. The same authorities are given the possibility of giving preferential treatment to enterprises with foreign capital in the old urban areas of the cities. The provincial People's Governments propose measures to attract foreign investment to the State Council for approval.

In June 1988 the latest expansion came as the Ministry of Finance issued temporary provisions giving possibilities for tax reductions for foreign enterprises in the whole of the Liaodong and Shandong peninsulaes, in the Zhangjiang and Zhujiang deltaes and in coastal municipalities in Fujian province. The provisions name the areas together as coastal open economic areas (yanhai jingii kaifang $q u$ ). This last measure is a consequence of a more comprehensive plan for development of the Chinese economy by opening to the outside world, known as the "coastal region strategy « (yanhai diqu jingii fazhan zhanlïe) promulgated by Zhao Ziyang in 1987. The coastal region strategy argues for a very uneven economic development of the whole country by concentrating resources on further development of the whole of the east coast, making it one huge special economic region with very favorable conditions for foreign investors. This strategy is presented as a national rather than a regional policy where the opening of the coast area is to be used as the engine for development pushing national reform forward. Some economists and politicians see this strategy as the beginning of a whole new phase in reform of the foreign economic relations and trade system. ${ }^{4}$

This strategy advocates using China's cheap high-quality skilled workers and technical personnel in large and mediumsized urban industrial 
enterprises to develop an internationally competitive industry producing technology- intensive goods. The objective is not, as could be assumed, to absorb the large rural surplus labour force into labour- intensive industries producing light industrial goods for export. ${ }^{5}$ These new industries shall use Chinese transnational corporations (kuaguo jituan gongsi) as their main operational entities to go out and »conquer the world market. " ${ }^{6}$ These transnational corporations shall develop from already existing large industrial enterprises, trade enterprises or financial enterprises and they shall have a great deal of functional diversity. Production, trade, technology transfer, financial operations, and overseas investment shall be managed by one company.

Overseas investment by Chinese investors is already an integral part of China's opening to the outside world. In March 1989 the State Council for the first time promulgated a set of rules for management of overseas investment stipulating, among other things, that each investor should pay a guarantee $-5 \%$ of the investment in foreign exchange - to ensure the timely repatriation of the firm's profit. Up to now Chinese investors have established more than 500 joint ventures and other cooperative undertakings in 70 different countries, with the total contract value exceeding 2 billion US dollars. However, there have been some problems getting the profit back to China as required, some firms have used the money for other purposes, and the new rules are an attempt to prevent this diversion.

\section{Problems}

\section{Reasons for reform}

The arguments behind the decentralization of the foreign trade system follow the arguments for the general reform of industrial management, i.e. bureaucracy and central control strangled enthusiasm and vitality in the enterprises and made them economically ineffective. To solve these problems experiments were made directed at separating ownership rights (or government rights) from management rights and concentrate power, responsibility, and benefit (quan, $z e, l i$ ) at the enterprise level, and this seems still to be the ultimate objective of the reform. The contract responsibility system was chosen as the way to bring about this functional separation, and by $1987,80 \%$ of all state- owned enterprises were carrying out the responsibility system. As mentioned above this system were not thoroughly implemented in the foreign trade sector before 1988. 
Apart from that, the foreign trade system had the special problem of bridging the gap between China's producers and the world market. The overly centralized structure of the old system created an »air-lock « between the two parties, where the FTCs were the main point of contact between China and the world market. That meant that Chinese enterprise managers had only limited contact with foreign buyers and suppliers and had no knowledge of (or interest in) the price level at the international market. They sold their products to the FTCs, who then shouldered the responsibility of getting rid of them again. To strengthen the contact between seller and buyer the agent system was introduced and the monopoly of the ministerial FTCs was discarded. The agent system gives a much closer contact to the end-user, and the producer derives a direct benefit from high quality, timely delivery good packing, etc. of his product. The FTC acts as a go-between to assist the manufacturer in negotiating and signing contracts and handle the necessary commercial formalities. Whether the negotiated prices and other conditions are acceptable is the decision and responsibility of the production units themselves. The end of the monopoly means, that the enterprise manager can select another. agent, if he is dissatisfied with the service offered, and he can then maybe enhance his profit. That means connection between power, responsibility and benefit. So runs the argument, but...

\section{Critique of the Decentralization Reform}

The reforms naturally have created a whole range of problems and have had more or less unforeseen consequences. A common critique of the contract responsibility system is that it does not fundamentally eradicate the vices of the old system.

The regional contracting system is merely an improvement and a perfection of the old system under new circumstances rather that the inevitable outcome of deepening reform of the foreign trade system. Abandonment of the local regional form of contracting may be regarded as a more scientific choice for perfecting the foreign trade contracting business system and the deepening of foreign trade system reform.

Thus reads an article in the influential reform-minded the World Economic Herald (which actually was closed down in April 1989 because of its support to student demonstrations in Beijing) in December 1988. The article 
proposes to discard the foreign trade regional contracting system and to institute direct competitive contracting among enterprises. It is stated that the present system still lacks a competitive mechanism and therefore the defects of the old control methods have not been overcome, in fact they have rather been strengthened. A system of direct competition is called for, in which the state still issues contracts, but then calls for bids and has entrepreneurs submit tenders. In this way a clear demarcation is introduced between the one issuing the contract and the contractor. Under the present system of regional contracting the interests of the two parties are almost identical, and the organizational structure of the old system is used as a compulsory measure for completing the state foreign trade plan. So the separation of ownership from operation is not completed.

The call for competitive contracting touches the problem of who actually benefits from the decentralization to the lower administrative level. By not passing real power down to the level of producing enterprises - as would be the case if the enterprises had the opportunity to submit tenders - the old local bureaucrats are actually strengthened with the weakening of central control. The provincial authorities are the ones who chooses the contracting partner and the biggest part of the retained foreign exchange - besides the portion delivered to the state - also ends in the provincial treasury. This creates sound opportunities for different kinds of corruption and by-gains as numerous examples have shown. The most famous being the socalled Hainan-scandal in 1984, where the whole of Hainan island, led by the local government, were engaged in illegal dealing with imported goods. As a special privilege Hainan was allowed to import goods duty-free and this right was used to import luxury goods like cars and coloured TV-sets with the aim of earning a big profit by selling them to other parts of China.

Another argument against the reform is that the conflicts between exports made and returns realized (that is the economic loss of export) have only been pushed down to lower levels. The national "large pot« has become a local "medium-size pot, « because the foreign trade enterprises never have been truly responsible for own profits and losses. If they do not fulfill their contracts, they are being subsidized by the state. They have traditionally been, and still are, treated as unprofitable enterprises, and they are in no way prepared to compete in the international market. ${ }^{8}$ So the crux of the matter lies with the real economic responsibility of the enterprises, which has not been enforced yet. To do justice to the reformers, it 
need be added, that the contract responsibility system usually is not mentioned as the ultimate goal, but as the method by which the enterprises gradually should become able to shoulder their own responsibilities. The question is whether the true responsibility for own profit and loss right away would not create so many bankruptcies in the foreign trade sector that the social and economic problems involved would be hard to tackle. The discarding of the monopoly of the FTCs in fact has created some kind of competition. The old FTCs were specialized in as many different groups of products as there were corporations, so no overlapping occurred. But as a result of the reform several corporations trade in the same product and fierce competition has occurred, creating severe losses in the state foreign exchange earnings. An export drive has also led to excessive export of products badly needed in China, so while sticking to the necessity of export competition, the state now urges exporters to compete with the country's general interests in mind.

On the import side the problem lies in recklessness and impetuosity from the Chinese importers. The gap in technology and technique between the imported equipment and the existing conditions is often too big to give a positive economic result. The Cherokee Jeep Manufacturing Plant in Beijing is often used as an example. The technology imported was mid-1980 standard, but the level of China's car industry is 30 og 40 years behind advanced world level. So still $57 \%$ of the parts have to be imported, because Chinese parts are either of poor quality or more expensive than imported parts.

The agent system is not suited to the present conditions and very difficult to carry out, according to my own interviews in August 1989. The enterprises - many of them inexperienced in foreign trade are not able to judge the feasibilitybility of prices and other conditions, and they do not have the power to conduct all the formal procedures, so the old procurement system is still preferred. As one manager puts it: »The state has only given us a new policy, they have not given us a new power. «The question of foreign exchange is also a problem, because many enterprises lack a stock of foreign ecxhange to cover eventual losses, which frequently occur in export transactions because of the grossly overvalued RMB. Another factor might be that the foreign trade corporations actually earn less money by being agents than by trading themselves. So they may be reluctant to introduce the agent system by educating the enterprise managers; for instance, they have their own plan targets to fulfill, so why should they 
invest in a system that gives them more work for the same income?

Some enterprises, actually, are said to exert every effort to bypass the import/export corporations, because they feel that the corporations are earning foreign exchange at their expense. For instance, the prices by which their products are sold at the international market are kept secret, which might enhance some enterprise manager's feeling of being cheated. Some enterprises want to get the foreign exchange themselves to import equipment or consumer goods, so the right to trade directly, not even through agents, seems to be a coveted privilege among these enterprises, but very hard to obtain. One example: of 480 light industry enterprises in Harbin city only 7 had direct trading rights.

\section{Problems with foreign exchange}

As an overall assessment and analysis of the question of direct foreign investment in China has been treated elsewhere ${ }^{9}$, it should not be repeated here. Instead a few concrete problems seen from the Chinese side will be touched upon.

A big question for the foreign funded enterprises is the question of foreign exchange, and the remittance of profits abroad. Article 75 of the "Regulations for the Implementation of the Joint Venture Law" states: "A joint venture shall in general keep a balance between its foreign exchange income and expenses. « The reasons for this clause is obvious from the Chinese side: the joint ventures shall not be allowed to drain the state's precious foreign exchange reserves. But in practice it can be difficult within one enterprise to have such balance always and have foreign exchange for the lawful remittance of profits. In 1988 the proportion of total exports from foreign-funded enterprises to materials imported for processing was $89,3 \%$. As a result, the foreign exchange balance issue has become a critical factor in foreigners' decision to invest in China. So different methods of circulating surplus foreign exchange between the enterprises have been tried.

One method is to develop a regular market for foreign exchange. In 1985 the first so-called "Foreign Exchange Adjustment Center" were opened in Shenzhen, and by early 1989 a total of 57 such centers in all were scheduled to be operating throughout China. Joint ventures are allowed to trade foreign exchange at the centers; not all Chinese enterprises are, but the guidelines have not been issued. In the beginning a ceiling existed on the allowa- 
ble exchange rate, but it has now been abolished and the gap between the official exchange rate and the rate at the centers have risen to as much as $70 \%$ at times.

The provincial governments also have offered a similar kind of service since 1985. Enterprises can sell their foreign exchange credits to a government agency at the official rate. The agency then sells the foreign exchange at a much higher rate (close to that prevailing at the adjustment centers) to enterprises and projects in need of hard currency - and keeps the difference. In view of the low rate of exchange, the seller may receive various forms of additional compensation from the government, such as extra allocation of raw materials.

Other methods to resolve the enterprises' foreign exchange problems have been tried out: 1) To allow foreigners to reinvest their portion of RMB profits and enjoy preferential treatment. This is not always a solution to the problem, for the next project may end up with the same negative foreign exchange balance. 2) Provide full compensation. A foreign businessman can get compensation in $\mathrm{RMB}$, with which he can procure domestically produced goods for export. This, however, only solves a limited number of foreign exchange balance problems since there are restrictions on purchases of unified managed products for exports by foreigners. And few non-unified managed goods can be provided due to low quality standard, limited quantity, etc. 3) Have foreign exchange secured loans in RMB. A joint venture may use idle foreign exchange as security for a RMB loan, which enables it to acquire needed RMB funds without converting any more foreign exchange. That is a way of saving foreign currency, to be used later in case of shortage. 4) Substitute products for imports. The joint venture can apply for permission to substitute some of its own products for imports. In case of advanced technology or equipment such a permission is usually given, and that leaves the foreigner with his dollar in his hand. But still this method cannot solve all the cases. ${ }^{10}$

The joint venture may not only lack foreign exchange, but working capital at large, and this problem has been treated in Sichuan, where 13 Sinoforeign joint ventures together with Foreign Exchange Affairs Bureau of the Commercial and Industrial Bank of China in May 1988 jointly set up the "Sichuan Foreign Invested Enterprises Mutual Assistance Foundation. "The foundation uses bank and enterprise funds. Funds may be allocated to enterprises upon application. The foundation stipulates that each member must deposit a minimum of 20.000 US dollars in the fund. The 
bank involved provides that foundation members may borrow 8 RMB for each dollar deposited. So idle funds in one enterprise are able to work for another enterprise.

\section{Rising land prices in the zones}

Of the zones Hainan Island has the most liberal investment climate, f.ex. the province has the advantage of being allowed to transfer land use rights within a maximum term of 70 years (as against 50 in most of the other zones), and this right can be transferred, mortgaged, sold and inherited by parties other than the original owner. Within the next ten years, Hainan may keep all the economic benefits it can get out of the land without sharing with the state (other zones must deliver a percentage of the profit to the state). The aim of these privileges is, naturally, that Hainan should lower its price of land to attract investors and facilitate its own development. But on the contrary land prices are rising so fast, that they scare investors away, and the land market is chaotic. Prices between 5.000 and 10.000 Yuan pr. $\mathrm{m}^{2}$ have been mentioned followed by demand of personal, under-the-table cash rebate or other services. The provincial authorities have been urging localities to lower the price of land, but they lack management rules and regulations to enforce price reductions.

In Shenzhen the land prices are also on the rise. The record auction for land is now $4.700 \mathrm{Yuan}$ per $\mathrm{m}^{2}$ and this seriously affects the investment environment in the zone. Measures are now being worked out by the authorities to impose price limits on real estate in stages. The problem is an illustration of how political,economic measures, promulgated to facilitate a certain development, creates new, and maybe unforeseen, problems. The liberalization embodied in the permission to transfer land use rights has to be curtailed by the imposition of new regulations.

\section{Recent Trend: "Recentralization"}

Trends towards tighter control and some kind of centralization measures can be discerned for the nearest future, albeit MOFERT is formalizing the decentralization at the highest level by reorganizing and cutting its staff by $22 \%$ from 1352 to 1055 employees. As of January 1, 1989 all of the ministry's "bureaus" will be called "departments, " indicating the movement away from direct management to administrative functions. At the same time the 
most important tasks for 1989 are formulated by MOFERT minister Zheng Tuobin as: "the policy of controlling the economic climate and reorganizing the economic order, control and reorganize the foreign trade climate and order and actively develop exports. " ${ }^{11}$ As an answer to this the State Council in March 1989 issued a circular calling upon various regions and departments to check up on and rectify foreign economic operations and trade companies. Its main purpose is to ssolve the problems of government administration not being separated from enterprise functions, government affairs not being separated from commercial matter, illegal operations, business dislocations, and chaotic management. $\ll^{12}$ The circular stresses the fact that the FTCs actually are relieved of their government administrative functions (except a small number which is directly authorized by the State Council), and orders that all foreign economic trade companies approved since January 1988 are to be reexamined and have to undergo a new approval procedure.

A general impression in China at the moment is, in fact, that much effort is concentrated on screening and consolidating foreign trade enterprises and companies. Some are closed down, some are merged.

Along the same lines managers of some important import and export corporations gathered by MOFERT in Beijing warn about serious problems in China's foreign trade in 1989. Major reasons mentioned are:

- Sharp rises in purchasing prices of goods, for export, due to internal inflation.

- Shortage of foreign exchange. It is stated that many FTCs cannot afford to buy urgently needed raw material (and this was the situation before the "Beijing turmoil« seriously aggravated China's foreign exchange problems).

- Lack of transportation facilities.

- Disorder in the environment of foreign trade. That is, too many companies engaged in import and export.

The remedies proposed to ease the situation all imply state intervention:

- State monopolization of important import goods.

- State allocation of preferential loans to certain kinds of exporters.

- State ordered priority to the transportation of raw materials used in the production of export goods in $1989 .{ }^{13}$ 


\section{Concluding Remarks.}

Traditionally centralization in China has persisted through the ingrained channels uniting ownership rights and management rights, underlining the government's ultimate power right down to the level of production enterprises. As other ways of controlling through legislation, indirect economic levers and the like are still very new and weakly based in the Chinese bureaucracy, it is difficult to envisage how a control and consolidation drive can take place without harming the perceived, clearly formulated goal of separating the government and the enterprise functions. So maybe in two years time we again will hear complaints about the lack of economic vitality and enterpreneurship in the Chinese enterprises.

The Tian An Men incident in June 1989 have also had a serious impact on China's foreign economic relations pushing in the same direction and aggravating the above-mentioned problems. The shortage of foreign exchange and the bottle- necks in energy and transportation, which needed foreign investment to be solved, have all been worsened because of the Western world's prompt reaction to the shooting down of demonstrators in the center of Beijing at the 4th of June last year. The World Bank, US, and the EEC member states immediately cancelled all negotiations on new contracts and froze aid projects for more than 10 bio US dollars. Most seriously were probably the freezing of 7 World Bank loans at a total worth of 780 mio US dollars earmarked for power and transport projects, and for industrial development of Shanghai. The investors who already have a firm basis in China seems to be staying, but new one has been scared away by this sign of grave political instability. For instance the development of the Hainan SEZ, which was just in the making, seems to be almost halted. Also badly hit is the revenue from tourism. Tourists virtually stopped coming immediately after the June incident, and though the traffic slowly began to accelerate during August and September the tourist income for the whole of 1989 is only $50 \%$ of the 1988 figure.

The Chinese have firmly upheld the view that nothing is changed in the open door policy and they welcome foreigners as much as before, but the security authorities seem to have tightened communication between Chinese and foreigners, mostly in the realm of academic exchange, but there have also been restrictions on Chinese businessmen going abroad, probably more caused by the present economic austerity programme than by fear of poisonous Western influence. All in all, the Chinese economic 
relations with the rest of the world must be said to have suffered greatly from last year's political disturbances.

Hatla Thelle is a Research Associate at the Center for East and Southeast Asian

Studies, University of Copenhagen.

\section{NOTES}

1. "Guowuyuan pizhun duiwai jingii 7. Qiu Demin, "Institute Competitive maoyi bu guanyu waimaotizhi gaige yijian de baogao de tongzhi« (Resolution from the State Council Approving a Report from the Ministry of Foreign Economic Relations and Trade Concerning Reform of the Foreign Trade System), Zhonghua Renmin Gongheguo Fagui Huibian, September 15, 1984, pp. 377-383.

Contracting Among Foreign Trade Businesses and Discard the Regional Contracting System, « Shijie Jingji Daobao, December 12, 1988, p. 10, JPRSCAR-89-018, pp. 41-42.

8. Shen Yejun, »Roundup of International Trade Association Annual Meeting," Shijie Jingji Daobao, December 26th, 1988, p. 2, JPRS-CAR-89-016, pp. 25-26.

2. Wu Zesong, »Improve the Foreign Trade Financing Accounting System and Perfect the Foreign Trade Contracted Managemet Responsibility System, " Guoji maoyi wenti, 1988, No. 11, pp. 9-13, JPRS-CAR-89-016, pp. 29-33.

3. Renmin Ribao, March 7, 1989, p. 1.

4. For instance Zhang Songtao, "Guanyu woguo waimao tizhi gaige wenti," (Problems in relation to reform of our foreign trade system), Guoji maoyi wenti, 5, 1989, pp. 18-23.

5. Xia Shen, »On Strategy Options for the Development of China's Externally Oriented Economy, With Comments on the Strategic Concept of the 'Great International Circle', "Caimao Jingji, 9; 1988, pp. 11-16, JPRS-CAR-89-010, pp. 37-44.

6. Wang $\mathrm{He}$, "Fazhan Zhongguo tese de huaguo jituan gongsi« (On the development of China's transnational corporations), Guoji Maoyi, 5, 1989, pp. 4-9.

9. Among many others see for instance The World Bank Country Study: China: External Trade and Capital, Washington D.C., 1988, pp. 247-273; and Samuel P.S. Ho and Ralph W. Huenemann, China's Open Door Policy: The Quest for Foreign Technology and Capital (Vancouver, 1984).

10. Yu Shiyuan, "Discussion on Solving Foreign-Funded Enterprises Balance of Foreign Exchange Problems, "Caimao Jingji, October 1988, 10, 11, pp. 52-53, 48, JPRS-CAR-89- 012, pp. 33-36.

11. $\gg$ Zheng Tuobin, MOFERT minister, Plans 1989s work; Functions Must Be Further Changed and Foreign Economic Relations and Trade Developments Must Be Speeded UP, " Guoji Shangbao, January 5, 1989, p. 1, JPRSCAR-89-019, pp. 16-17.

12. Renmin Ribao, March 9, 1989, p. 1.

13. »Managers Warns of Foreign Trade Problems« JPRS-CAR-89- 011, p.:34. 